\title{
EFFECTS OF ICE STORAGE ON THE BIOCHEMICAL COMPOSITION OF Macrobrachium vollenhovenii (Herklots, 1857)
}

\author{
*AKINTOLA, S.L ${ }^{1}$ AND BAKARE, S.B ${ }^{2}$ \\ ${ }^{1}$ Department of Fisheries Faculty of Science, Lagos State University, Ojo, Lagos State \\ 2 Department of Microbiology, Faculty of Science, Lagos State University, Ojo, Lagos State
}

Copyright 2010, Fisheries Society of Nigeria.

This paper was prepared for presentation at the $25^{\text {th }}$ Annual International Conference and Exhibition in Administrative Staff College of Nigeria (ASCON), Topo-Badagry, Lagos, Nigeria, $25^{\text {th }}-29^{\text {th }}$ October, 2010

This paper was selected for presentation by an FISON Program Committee following review of information contained in an abstract submitted by the author(s). Contents of the paper, as presented, have not been reviewed by the Fisheries Society of Nigeria and are subject to correction by the author(s). The material, as presented, does not necessarily reflect any position of the Fisheries Society of Nigeria, its officers, or members. Papers presented at FISON meetings are subject to publication review by Editorial Committees of the Fisheries Society of Nigeria. Electronic reproduction, distribution, or storage of any part of this paper for commercial purposes without the written consent of the Fisheries Society of Nigeria is prohibited. Permission to reprodu in print is restricted to reproduce in prin is restricted to an abstact of not more than 300 words; ilustrations may not be copied. The abstract must contain conspicuous acknowledgement of where and by whom the paper was presented. Write Librarian, Fisheries Society of Nigeria (FISON), P. O. Box 2607 Apapa,
Lagos.

\section{ABSTRACT}

Changes in biochemical properties of freshwater prawn stored with two ice conditions Without Direct Contact with Ice (DCI) and Without Direct Contact with Ice (WCI) for day 0, 2, 4, 6, 8 and 10 were investigated. Proximate composition defined in terms of moisture increased for the DCI as storage days increases but relatively constant with treatments with WCI. Values of TVB-N (mgN/loog) in prawn stored with DCI had inverse relationship with storage days but increased with storage days in the WCI. Changes in the values of ash and crude protein were relatively constant as the storage days increased in both treatments. Ice treatments recorded little changes in between storage days for fats. Values of NPN mgN/100g decreased with days of storage with DCI but increased as the storage increased with WCI. These results obtained in this study showed that ice storage may have contrasting values and importance on the biochemical properties of the freshwater prawn.

Keywords: Macrobrachium vollenhovenii, Ice, Biochemical, Sensory, quality, shelf life.

\section{INTRODUCTION}

Ice storage of prawns is the cheapest and the most common preservative method which is very efficient and utilized worldwide (Madrid and Philips 2000). Chemical and biochemical reactions responsible for quality deterioration during storage will slow down with decrease in storage temperature, and the storage life will be prolonged at lower temperatures (Riaz and Qadri, 1990). The more rapid spoilage of the shellfish are due to higher water content, high free amino acid content, more rapid autolysis by the existing enzymes and less reaction of the flesh that favours microbial growth and the lower content of connective tissue as compared to other flesh foods.

The proximate and chemical composition of finfish and shellfish and from different literatures had been exhaustively reported by Krzynowek and Murphy (1987). Also, the impact of storage conditions on the freshwater prawn have been reported by Kye et al., (1988), for Macrobrachium rosenbergii, Dinakaran and Soundarapandian (2009) for Macrobrachium idella idella. Information on the impact of ice on the proximate composition on Macrobrachium vollenhovenii is rare. The objective of this study was to investigate the proximate composition fresh and ice stored Macrobrachium vollenhovenii, African giant river prawn.

\section{MATERIALS AND METHODS}

Live Macrobrachium vollenhovenii with mean weight of $30 \pm 25 \mathrm{~g}$ were purchased from fishers from Badagry Creek, 
longitude $2^{\circ} 42^{\prime}$ and $3^{\circ} 23^{\prime} \mathrm{E}$ and latitude $6^{\circ} 23^{\prime}$ and $6^{\circ} 28^{\prime} \mathrm{N}$ in hours of 7.00-8.00 am. Samples were packed into a sterile Thermocool ${ }^{\circledR} \quad$ boxes containing chlorinated water $(5 \mathrm{ppm})$ and transported within $1 \mathrm{~h}$ to the laboratory in the Department of Fisheries, Lagos State University.

Samples were aseptically distributed randomly into two groups of prawn stored with direct contact with ice (DCI) in ratio of $1: 1(\mathrm{w} / \mathrm{w})$ in Thermocool ${ }^{\circledR}$ box labelled A while the samples without direct contact with ice were placed $0.006 \mathrm{~mm}$ thick polythene bags, 150g prawn/bag following Kirschnik et al. (2006) and thereafter placed in the Thermocool ${ }^{\circledR}$ box labelled B. Melted ices in each box were replaced after 12hours and drained regularly through the tap on the Thermocool ${ }^{\circledR}$ box. Five prawns were withdrawn for proximate and chemical analyses the first day and thereafter every two days of storage (Day 0, 2, 4, 6, 8, 10) from the two experimental set up under room temperature of $27-30{ }^{\circ} \mathrm{C}$ while the fresh prawns served as control.

Moisture, ash, fat, crude proteins, muscle, $\mathrm{pH}$, Thiobarbituric Acid (TBA), Total Volatile Bases-Nitrogen (TVB-N), were determined using the methods in AOAC (1984). Non-Protein-Nitrogen (NPN) determined by copper sulfate method (Osborne and Voogt, 1986)

\section{Statistical analyses}

The data were analysed by ANOVA using SPSS (version 15). Mean values were reported and significance was defined at $\mathrm{P}$ $<0.05$.

\section{RESULTS AND DISCUSSION}

The highest moisture content was obtained in day 10. Moisture in the DCI increased with storage days whereas values for WCI was relatively constant (Table 1). This agreed to the work of Joseph et al.,(1998) and Basavakumer et al.,(1998) both reported increased moisture content of Penaeus indicus and P.monodon stored in
DCI respectively. Similarly, lower increase in moisture (1-5\%) recorded in WCI agrees with Angel et al. (1986). The Ash content remains fairly constant in both storage conditions, Crude protein decreased in DCI with storage days but relatively constant for WCI. The crude protein content of WCI differed significantly $(\mathrm{P}<0.05)$ from DCI. Basavakumar, et al., (1998) reported reduced protein values in muscle of P.monodon after 7days of DCI which is due to the leaching out of the soluble component in water and to the dilution effect caused water absorption. This agrees with observed values in both treatments. Also Bauer and Eitenmiller (1976) suggested that loss of protein and non protein Nitrogen in interstitial fluid may be due to cell rapture during ice storage.

Values of the Total Volatile Base Nitrogen (TVB-N) decreased significantly $(\mathrm{P}<0.05)$ as the storage days increased from $17.35 \pm 1.1 \mathrm{mgN} / 100$ to $04.85 \pm 1.06 \%$ $\mathrm{mgN} / 100$ in DCI whereas for WCI, values observed increased from 17.35 \pm 1.1 $\mathrm{mgN} / 100$ to $21.89 \pm 0.86 \mathrm{mgN} / 100 \mathrm{~g}$ with increased storage days. In this study, continuous reduction occurred in TVB-N in DCI storage sample while there was slight increase in the TVB-N content on the $10^{\text {th }}$ Day in WCI storage contrary to the report of Mausse (2000). In this study the values of TVB-N obtained are within the acceptable limits reported for fish i.e $<30 \mathrm{mg}$ N/100g muscle, Brazil (1997).

The fat content in the muscle of iced stored freshwater prawn in this study had values which changed only by $4.34 \%$ $13.03 \%$ consistently in the storage days for both storage conditions. In DCI storage, Thiobarbituric Acid (TBA) content remain almost same $(<1.0)$ but increased from $0.05 \mathrm{mg}$ to $1.16 \mathrm{mg}$ malonaldehyde $/ \mathrm{kg}$ of muscle on Day8 in WCI storage may be due to the oxidation of polyunsaturated fatty acids from the muscle, caused by the presence of oxygen inside the plastic bag (WCI). In DCI, the prawn sample was placed directly in ice which may probably 
reduced the contact with oxygen and delayed oxidation. Kanner and Karel (1976), reported that lower Thiobarbituric Acid (TBA) content was due to leaching out of Malonaldehyde together with amino acid accumulated during DCI storage (Table 2).

The non-protein Nitrogen (NPN) reduced from 416.56461.56 $\pm 16.6 \mathrm{MgN} / 100 \mathrm{~g}$ to $170.28 \pm 29.2 \mathrm{MgN} / 100 \mathrm{~g}$ as the storage days increased for DCI while the values obtained for WCI increased as the storage days increased significantly $(\mathrm{P}<0.05)$ from $416.56 \pm 16.6 \mathrm{mgN} / 100 \mathrm{~g}$ to $538.04 \pm 07.5$ $\mathrm{mgN} / 100 \mathrm{~g}$ (Table 2). Changes in the $\mathrm{pH}$ in the muscle of the freshwater prawn exposed to two ice storage conditions in this study was relatively constant as the days of storage increased.

\section{CONCLUSION}

Prawn stored in direct contact with ice (DCI) and without contact with ice (WCI) presented biochemical analyses that would permit the consumption for at least 8 days. However, this may be confirmed in further study in terms of market acceptability.

\section{REFERENCES}

Angel, S., Juven, B.J., Weinberg, Z.G., Linder, P., and Eisenberg, E. (1986). Effects of radurization and refrigerated storage on quality and shelf-life of freshwater prawns, Macrobrachium rosenbergii. J. Food Protect. 49(2):142-145.

AOAC. (1984). Association of Official Analytical Chemists. Official Methods of Analysis, $14^{\text {th }}$ ed. Washington, DC.

Basavakumar, K.V., Bhaskar, N., Ramesh, A.M., and Reddy, G.V.S.(1998). Quality changes in cultured tiger shrimp (Penaeus monodon) during ice storage. J. Food Sci. Technol. 35(4): 305-309.

Bauer, B. A. and Eitenmiler, R.R. (1976). A study of some kinetic poperties $\mathrm{f}$ partial purified penaeus setiferus arylamidae. J. Food Sci. 39:10-14.

Brasil, Ministerio da Agricultura, pecuaria e abastecimento. Legioslacao de pescado e Derivados Brasilia, 1997. Portia n. 185, de 13 de maio de 1997-Diario official da Uniao 19 de maio de 1997.

Contreras-Guzman, E.S (1994). Bioquimica de pescados $e$ derivados., FUNEP, Jaboticabal, Brazil. Pp 409.

Dinakaran G.K. and P. Soundarapandian (2009) Biochemical Status of Edible Palaemonid Prawn Macrobrachium idella idella (Hilgendorf, 1898). Advance Journal of Food Science and Technology 1(1): 19-26

Hale, M.B. and Waters, M.E. (1981). Frozen storage stability of whole and headless freshwater prawns, Macrobrachium rosebergii. $\mathrm{M}$. Fish. Rev.43(12):18-21.

Joseph, J. Perigreen P.A., and Gopalakrishna-Lyer, T.S. (1998). Storage characteristics of cultured Penaeus indicus in ice and at ambient temperature. Fish. Technol. 35(2): 84-89.

Judith Krzynowek and Jenny Murphy (1987) Proximate Composition, Energy, Fatty Acid, Sodium, and Cholesterol Content of Finfish, Shellfish, and their Products. National Oceanic and Atmospheric Administration, NOAA Technical Report NMFS 55 p53.

Kanner, J. and Karel, M. (1976). Changes in lysozyme due to reactions with peroxidizing methyl linoleate in adehydrated model system. $J$. Agric. Food Chem. 24(3): 468-472.

Kanner, J. and Karel, M. (1976). Changes in lysozyme due to reactions with peroxidizing methyl linoleate in a dehydrated model system. J. Agric. Food Chem. 24(3): 468-472.

Kirshnick P.G. Vigas, E. M, Valenti W.C., and fermandes, C. A (2006). 
Shelf Life of tail meat of the Giant River Prawn, Macrobramchium rosenbergii, stored on ice. $J$ of aquatic food, product technol. 15(2):57-71.

Kye, H. W., W. K. Nip and J. H. Moy (1988) Changes of Myofibrillar Proteins and Texture in Freshwater Prawn, Macrobrachium rosenbergii, During Iced Storage Marine Fisheries Review 50(1),5356

Madrid, R.M.M. and Phillps, H. (2000). Post-harvest handing and processing. In: freshwater prawn culture, the farming of Macrobrachium rosenbergii (M.B. New and W.C valent Eds). Onsey Mead, Oxford, UK. Pp326-344.

Riaz, M. and Qadri, R.B. 1990. Time temperature tolerance of frozen shrimp. 2. Biochemical and microbiological changes during storage of frozen glazed shrimps. Tropical Science, 30: 343-349. 
Table 1: Mean Value ( \pm S.D) of Moisture, Ash content, Crude Protein and Total Volatile Base Nitrogen (TVB-N)

\begin{tabular}{|c|c|c|c|c|c|c|c|}
\hline \multirow[b]{2}{*}{ Parameter } & \multicolumn{7}{|c|}{ STORAGE (DAYS) } \\
\hline & Treatment & 0 & 2 & 4 & 6 & 8 & 10 \\
\hline \multirow[t]{2}{*}{ Moisture } & DCI & $77.86 \pm 16.2^{\mathrm{Ee}}$ & $79.38 \pm 20.8^{\mathrm{Rr}}$ & $81.76 \pm 16.2^{\mathrm{Rr}}$ & $82.14 \pm 27.2^{\operatorname{Tr}}$ & $83.94 \pm 12.0^{\operatorname{Tr}}$ & $84.62 \pm 29.2^{\operatorname{Tr}}$ \\
\hline & WCI & $77.86 \pm 16.2^{\mathrm{Ee}}$ & $77.74 \pm 10.7^{\mathrm{Ee}}$ & $77.74 \pm 16.3^{\mathrm{Ee}}$ & $77.16 \pm 20.8^{\mathrm{Ee}}$ & $77.02 \pm 21.0^{\mathrm{Ee}}$ & $77.60 \pm 07.7^{\mathrm{Ee}}$ \\
\hline \multirow[t]{2}{*}{ Ash $(\%)$} & DCI & $1.64 \pm 0.07^{\mathrm{Ee}}$ & $1.60 \pm 0.12^{\mathrm{Ee}}$ & $1.62 \pm 0.06^{\mathrm{Ee}}$ & $1.56 \pm 0.08^{\mathrm{Ee}}$ & $1.52 \pm 0.04^{\mathrm{Ee}}$ & $1.48 \pm 0.08^{\mathrm{Ee}}$ \\
\hline & WCI & $1.64 \pm 0.07^{\mathrm{Ee}}$ & $1.58 \pm 0.10^{\mathrm{Ee}}$ & $1.54 \pm 0.05^{\mathrm{Ee}}$ & $1.60 \pm 0.05^{\mathrm{Ee}}$ & $1.48 \pm 0.15^{\mathrm{Ee}}$ & $1.36 \pm 0.12^{\mathrm{Ee}}$ \\
\hline Crude & DCI & $19.12 \pm 0.19^{\mathrm{Ee}}$ & $17.80 \pm 0.50^{\mathrm{Rr}}$ & $17.10 \pm 0.21^{\mathrm{Rr}}$ & $16.16 \pm 0.39^{\operatorname{Tr}}$ & $15.22 \pm 0.40^{\operatorname{Tr}}$ & $14.34 \pm 0.42^{\operatorname{Tr}}$ \\
\hline Protein $(\%)$ & WCI & $19.11 \pm 0.15^{\mathrm{Ee}}$ & $10.30 \pm 0.53^{\mathrm{Ee}}$ & $19.58 \pm 0.37^{\mathrm{Ee}}$ & $19.72 \pm 0.14^{\mathrm{Ee}}$ & $19.96 \pm 0.54^{\mathrm{Ee}}$ & $19.49 \pm 0.38^{\mathrm{Ee}}$ \\
\hline TVB-N & DCI & $17.35 \pm 1.16^{\mathrm{Ee}}$ & $14.87 \pm 0.94^{\mathrm{Rr}}$ & $11.33 \pm 0.63^{\operatorname{Tr}}$ & $08.67 \pm 0.33^{\operatorname{Tr}}$ & $06.88 \pm 0.49^{\mathrm{Zr}}$ & $04.85 \pm 1.06^{\mathrm{Er}}$ \\
\hline$(\mathrm{mgN} / 100 \mathrm{~g})$ & WCI & $17.35 \pm 1.16^{\mathrm{Ee}}$ & $18.51 \pm 2.06^{\mathrm{Re}}$ & $18.71 \pm 0.95^{\mathrm{Ee}}$ & $20.17 \pm 1.46^{\mathrm{ERe}}$ & $21.32 \pm 0.86^{\mathrm{ERe}}$ & $21.89 \pm 0.86^{\mathrm{Re}}$ \\
\hline
\end{tabular}

Note: Mean values in the same row followed by different capital letter and mean values of some parameter in the same columns within a block, followed by different lowercase letters, are significantly different $(\mathrm{P} \leq 0.05)$. Mean values obtained from three samples analysed in triplicate. 
Table 2: Mean Value ( \pm S.D) of Fat, Non Protein Nitrogen (NPN), Thiobarbituric acid (TBA), and the pH in the muscle of M. vollenhovenii under different ice storage condition.

\section{STORAGE (DAYS)}

\begin{tabular}{|c|c|c|c|c|c|c|c|}
\hline Parameter & Treatment & 0 & 2 & 4 & 6 & 8 & 10 \\
\hline \multirow[t]{2}{*}{ Fat $(\%)$} & DCI & $0.46 \pm 0.09^{\mathrm{Ee}}$ & $0.52 \pm 0.07^{\mathrm{Ee}}$ & $0.48 \pm 0.09^{\mathrm{Ee}}$ & $0.56 \pm 0.10^{\mathrm{Ee}}$ & $0.54 \pm 0.05^{\mathrm{Ee}}$ & $0.48 \pm 0.04^{\mathrm{Ee}}$ \\
\hline & WCI & $0.46 \pm 0.09^{\mathrm{Ee}}$ & $0.48 \pm 0.08^{\mathrm{Ee}}$ & $050 \pm 0.16^{\mathrm{Ee}}$ & $0.52 \pm 0.08^{\mathrm{Ee}}$ & $0.48 \pm=0.08^{\mathrm{Ee}}$ & $0.44 \pm 0.04^{\mathrm{Ee}}$ \\
\hline NPN & $\mathrm{NCI}$ & $461.56 \pm 16.6^{\mathrm{Ee}}$ & $389.72 \pm 19.0^{\operatorname{Er}}$ & $310.34 \pm 16.6^{\mathrm{Rr}}$ & $215.64 \pm 27.62^{\mathrm{Rr}}$ & $217.88 \pm 12.26^{\operatorname{Tr}}$ & $170.28 \pm 29.2^{\mathrm{Zr}}$ \\
\hline$(\mathrm{mgN} / 100 \mathrm{~g})$ & WCI & $461.56 \pm 16.6^{\mathrm{Ee}}$ & $483.52 \pm 09.9^{\mathrm{Re}}$ & $509.48 \pm 16.7^{\operatorname{Tr}}$ & $514.63 \pm 21.00^{\mathrm{RTA}}$ & $530.67 \pm 21.00^{\mathrm{Te}}$ & $538.04 \pm 07.5^{\mathrm{Te}}$ \\
\hline TBA & DCI & $0.05 \pm 0.06^{\mathrm{Ee}}$ & $0.06 \pm 0.24^{\mathrm{Ee}}$ & $0.22 \pm 0.10^{\mathrm{Ee}}$ & $0.40 \pm 0.11^{\mathrm{Er}}$ & $0.55 \pm 0.10^{\mathrm{Ee}}$ & $0.35 \pm 0.06^{\mathrm{Er}}$ \\
\hline $\mathrm{MA} / \mathrm{Kg}$ & WCI & $0.05 \pm 0.06^{\mathrm{Ee}}$ & $0.12 \pm 0.16^{\mathrm{Ee}}$ & $0.85 \pm 0.45^{\mathrm{RTE}}$ & $1.32 \pm 0.48^{\mathrm{Rte}}$ & $1.16 \pm 0.38^{\mathrm{TEe}}$ & $0.02 \pm 0.51^{\mathrm{ZRe}}$ \\
\hline \multirow[t]{2}{*}{$\mathrm{pH}$} & DCI & $6.83 \pm 0.05^{\mathrm{Ee}}$ & $6.03 \pm 0.09^{\mathrm{Re}}$ & $6.68 \pm 0.06^{\mathrm{Ee}}$ & $6.63 \pm 0.08^{\mathrm{Ee}}$ & $6.53 \pm 0.04^{\mathrm{Ee}}$ & $6.46 \pm 0.05^{\mathrm{Ee}}$ \\
\hline & WCI & $6.83 \pm 0.05^{\mathrm{Ee}}$ & $6.79 \pm 0.07^{\mathrm{Re}}$ & $6.43 \pm 0.23^{\mathrm{Ee}}$ & $6.48 \pm 0.07^{\mathrm{Ee}}$ & $6.53 \pm 0.13^{\mathrm{Ee}}$ & $6.49 \pm 0.05^{\mathrm{Ee}}$ \\
\hline
\end{tabular}

$\mathrm{MA} / \mathrm{Kg}=\mathrm{mg}$ Malonaldehyde/kg of prawn muscle.

Note: Mean Values in the same row followed by different capital letters and means of the same parameter in the same columns within a block followed by different lowercase letters are significantly different $(\mathrm{P} \leq 0.05)$ Mean Values are obtained from three samples analysed in triplicate. 